\title{
Mining
}

\section{Temperature influence in cornstarch gelatinization for froth flotation}

\author{
André Carlos Silva \\ Professor Adjunto IV \\ Universidade Federal de Goiás - UFG \\ Departamento de Engenharia de Minas - DEMIN \\ ancarsil@ufg.br

\section{Elenice Maria Schons Silva \\ Professora Adjunta I \\ Universidade Federal de Goiás - UFG \\ Departamento de Engenharia de Minas - DEMIN eschons@ufg.br}

\section{Antônio Eduardo Clark Peres \\ Professor Emérito \\ Universidade Federal de Minas Gerais - UFMG \\ Departamento de Engenharia Metalúrgica - DEMET \\ aecperes@demet.ufmg.br}

\section{Débora Nascimento Sousa \\ Professora DII \\ Instituto Federal Goiano - IFGoiano \\ debora.nascimento@ifgoiano.edu.br}

\begin{abstract}
Starches are widely used as depressant in froth flotation operations in Brazil due to their efficiency, increasing the selectivity in the inverse flotation of quartz, depressing iron ore. The starch market has been growing and improving in recent years, leading to better products attending the requirements of the mineral industry. The major source of starch used for iron ore is the cornstarch, which needs to be gelatinized, by heat or sodium hydroxide $(\mathrm{NaOH})$ addition (also known as caustisized starch), prior its use. This stage has a direct impact on industrials costs, since the lower consumption of $\mathrm{NaOH}$ in gelatinization provides better control of the $\mathrm{pH}$ in the froth flotation and reduces the amount of electrolytes present in the pulp. In order to evaluate the influence of temperature on the $\mathrm{NaOH}$ consumption, gelatinization tests were carried out with temperatures ranging from 25 to $65{ }^{\circ} \mathrm{C}$, measuring the volume of $\mathrm{NaOH}$. All tests were performed in triplicate. A linear model correlating the temperature and the $\mathrm{NaOH}$ need for the cornstarch gelatinization has been stablished. This model can allow mineral industries to optimize the $\mathrm{NaOH}$ amount used to prepare the depressant used in froth flotation. For example, the reduction in $\mathrm{NaOH}$ could easily reach $480 \mathrm{~L}$ per ton of cornstarch when performing gelatinization with the cornstarch solution at $35^{\circ} \mathrm{C}$ instead of $25^{\circ} \mathrm{C}$ (reduction of approximately $34 \%$ in the $\mathrm{NaOH}$ consumed).
\end{abstract}

Keywords: froth flotation, gelatinization, cornstarch, sodium hydroxide, temperature.

\section{Introduction}

According to Peres and Corrêa (1996), cornstarch has been Brazil's default depressant for iron ore since 1978. Modified cornstarches are composed of amylopectin (70-80\%) and amylose (20$30 \%$ ) without impurities such as fibers, mineral matter, oils and proteins normally present in conventional starches. The authors point out that oil (triglycerides) present in conventional starch act as an antifoam agent spoiling the flotation process if its content exceeds $1.8 \%$. Several adsorption mechanisms for starches on mineral surfaces have been investigated, such as hydrogen bonding, electrostatic interactions, chemical adsorption, salt formation and hydrophobic bonding (Pinto, Araújo and Peres, 1992).

Turrer and Peres (2010) showed the importance of the amylose/amylopectin ratio in starch during hematite depression and point out that amylopectin reduces the hematite froth flotation more profoundly than amylose when a primary ether amine is used as a collector. According Iwasaki and Lai (1965) and Fillipov, Severov and Fillippova (2014) the effectiveness of the alkali gelatinization is strongly affected by the starch $/ \mathrm{NaOH}$ ratio used in the gelatinization. The last authors even suggest that alkali gelatinization has been studied less than the thermal method. Leal Filho et al (1993) showed that the alkali gelatinization is also affected by the dissolution technique.

The typical starch/ $\mathrm{NaOH}$ ratio is 5:1 (Iwasaki and Lai, 1965, Fillipov, Severov and Fillippova, 2013). Iwa- saki, Carlson and Parmeter (1969) and Guimarães, Araújo and Peres (2005) suggested that the starch solution was designed to yield a maximum concentration of $0.1 \% \mathrm{w} / \mathrm{w}$ and must be prepared daily to avoid retrogradation. However, this is not well stablished and other authors, as Cooke, Schultz and Lindroos (1952) disagree, using concentrations up to $3 \%$.

According to Shrimali and Miller (2016) starch is stirred in caustic soda solution with a constant ratio of starch/ caustic soda for a particular amount of time which is dependent on the size of the starch molecules. Due to thermal gelatinization, vibration between the hydrogen bonds in starch increases, which increases the penetration of water. The increase in water solubility of starch 
due to the addition of caustic soda is still not clear and is subject to further research. Larger starch molecules need more gelatinization time compared to smaller starch molecules. Liu, Zhang and Laskowski (2000) showed that the temperature needed for gelatinization decreases when increasing the amylopectin content. Retrogradation occurs spontaneously when starch solutions are stored at low temperatures at neutral $\mathrm{pH}$. The same authors showed that amylose's retrogradation might occur within a period of four to five hours after the gelatinization, while the amylopectin retrogrades only $10 \%$ within 100 days.

The primary adsorption mechanisms of starch on hematite were proposed as non-selective hydrogen bonding and electrostatic forces, mainly because of the presence of a large number of hydroxyl groups in starch molecules and on hematite surface. As confirmed by Mikhailova (1972), starch adsorbs more on a hematite surface than on a quartz one. According to Brandão, Caires and Queiroz (1994) the adsorption density of starch on a quartz

\section{Methodology}

The first stage aimed to characterize the cornstarch sample (donate by Cargill) in order to better understand its gelatinization. The cornstarch morphology was analyzed using a SEM, model Jeol JSM 6610. To determine the amylose content, a method proposed by the American Association of Cereal Chemists (AACC) number 1995 was used, which is a simple colorimetric procedure. Samples of cornstarch were added to a solution of $1 \mathrm{~mL}$ of acetic acid at 1 mol.L $\mathrm{L}^{-1}$ and $2 \mathrm{~mL}$ of solution of iodine-potassium iodide, which reacts with starch to form a blue colored complex. This complex is developed due to the imprisonment of iodine inside the chain of amylose. The solution was then stored for 30 minutes in a dark room and then using a spectrophotometer Biospectro, model SP220, we read the absorbance at $620 \mathrm{~nm}$. The content of amylose was calculated using the absorbance values read and a calibration curve was made with pure amylose (supplied by Sigma-Aldrich) in the range of 0.004-0.024 mg. $\mathrm{mL}^{-1}$ (for this curve the obtained fit was $\left.r^{2}=0.998\right)$. The results were expressed in $\mathrm{mg} \cdot \mathrm{mL}^{-1}$ and performed in triplicate. surface is approximately 10 times less than that on hematite. For pH's higher than 8 , the starch adsorption is almost nonexistent on the non-activated quartz surface, while it is noticeable on the hematite surface. According to Turrer and Peres (2010), the reasons for this selectivity are a better ability of the hematite surface to form hydrogen bonds with the depressant and the fact that a quartz surface is more negative than hematite, being the macromolecules slightly negative because of $\mathrm{OH}$ - adsorption. On the other hand, Iwasaki, Carlson and Parmeter (1969) proposed that the starch adsorption on hematite increases as the $\mathrm{pH}$ value decreases. Kar et al. (2013) tested four different starches (soluble starch, cornstarch, potato starch and rice starch) as iron ore depressants. According to the authors, the maximum adsorption for all the four starches with hematite occurs at the $\mathrm{pH}$ ranging 5-9. However, soluble starch was found to be the better depressant at slightly alkaline $\mathrm{pH}$. An iron grade of $63-65 \%$ Fe with $85-88 \%$ recovery at a starch concentration of $400 \mathrm{~g} / \mathrm{t}$ was achieved by the authors.

Other vegetable species, such as cassava, potato, wheat, rice, arrowroot, can produce starch with potential to be used in flotation. The most attractive among them, considering the cost of production, is cassava, which grows widely in warm weather countries, with no need of fertilizers or soil correction. The major obstacle to its use is the absence of major suppliers. The starch fraction content (amylopectin + amylose) extracted from cassava is higher than in corn because proteins and oil contents are lower in cassava, which prevents the risk of froth suppression. According to Fillipov, Severov and Fillippova (2013) cassava starch shows higher viscosities than cornstarch, which is an indication of higher molecular weight that can lead to more effective depressant action. Potato flour has been used industrially in Europe, but there are no records of its use in the mining industry so far, mainly due the fact that potato degrades much faster than corn and has a high price (Ibrahim and Abdel-Khalek, 1992).
Cornstarch swelling power and solubility were also measured to calculate the amylose content in it. According to Denardin and Silva (2009) when starch molecules are heated in water, the crystalline structure is broken and the water molecules form hydrogen bonds between amylose and amylopectin, exposing its hydroxyl groups, causing an increase in the granule size (a swelling) and in its solubility. This swelling power and solubility varies according to the starch source, providing evidence of the interaction between the starch chains within the amorphous and crystalline domains. According to Leach, McCowen and Schoch (1959) the extension of these interactions is influenced by the ratio amylose/amylopectin due to molecular features distributed, molecular weight, degree, length of branches. The swelling power was obtained by the relationship between the final mass swelled and the starch initial mass. The starch solubility was calculated by the relationship between the soluble mass and initial amount of starch (expressed in percentage).

Finally, the temperature influence in the $\mathrm{NaOH}$ consumption was estab- lished through experiments using both solution temperature control and $\mathrm{NaOH}$ addition to it, avoiding the excessive use of $\mathrm{NaOH}$. Cornstarch samples of $20 \mathrm{~g}$ were placed in a $600 \mathrm{~mL}$ beaker on top of a heating plate Ika C MAG HS 4. Then $200 \mathrm{~mL}$ of distilled water at $\mathrm{pH} 7$ and different temperatures (ranging from 25 to $65^{\circ} \mathrm{C}$ ) were added to the sample and the solution was kept under agitation at 1,200 RPM using a mechanical stirrer Fisatom 712 to promote a complete dilution of the starch sample. A pH meter Hanna Instruments HI2221 was installed in order to read the solution $\mathrm{pH}$ and to provide temperature control. After the complete dilution of the cornstarch sample, the initial $\mathrm{pH}$ value was noted and the titration started. An aliquot of $1 \mathrm{~mL}$ of $10 \% \mathrm{NaOH}$ solution was added every 2 minutes to the cornstarch solution. Before a new addition of the $\mathrm{NaOH}$ solution, the $\mathrm{pH}$ was noted. The process was repeated until the point that the starch solution presented itself viscous and more transparent (also known as the turning point of the gelatinization). Four steps of the gelatinization process can be seen in Figure 1. All titration process was performed in triplicate. 

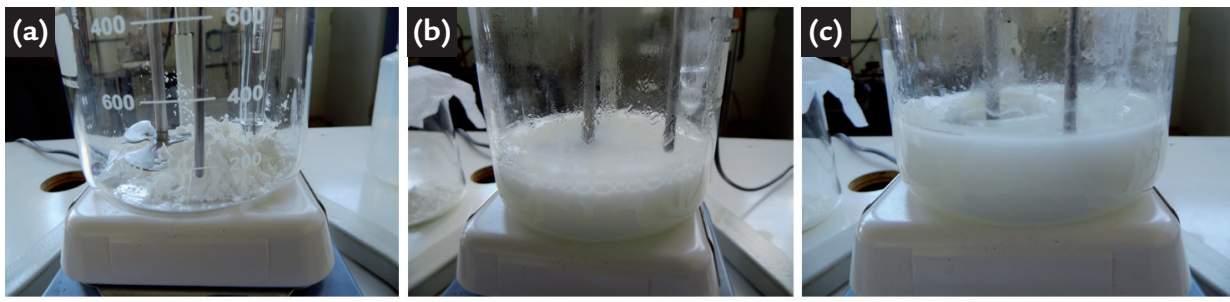

Figure 1

Six steps in the starches and flours alkaline gelatinization process.

(a) starch sample, (b) starch solution after complete solubilization, (c), (d) and (e) steps in the titration process and ( $f$ ) complete gelatinization of the sample.
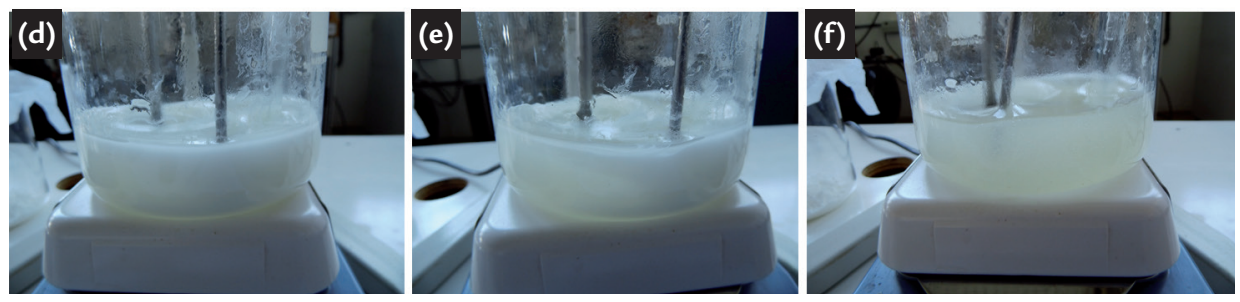

\section{Results and discussion}

Figure 2 shows the SEM results for the size and morphology of the cornstarch. The average grain diameter was $15 \mu \mathrm{m}$, with values ranging from 11 to $17 \mu \mathrm{m}$. No protein ribbons were visualized and some broken grains were detected. As expected, the cornstarch samples showed $71.62 \%$ of amylose and amylopectin $28.38 \%$. Cornstarch samples showed a solubility equal to $12.57 \%$ and a swelling power of $22.85 \%$. These values are significantly low compared to other starches. Weissenborn (1996) showed that high amylose starches show limited solubility and swelling power, even after a prolonged heating time.

Figure 3 shows the $\mathrm{NaOH}$ volume

consumed in the cornstarch gelatinization at different solution temperatures. As expected, the $\mathrm{NaOH}$ volume needed for the cornstarch gelatinization decreases with the increase of the temperature. An experiment at $65^{\circ} \mathrm{C}$ was performed in absence of $\mathrm{NaOH}$, being this the minimum temperature required for cornstarch gelatinization in absence of $\mathrm{NaOH}$. Temperatures lower than $25^{\circ} \mathrm{C}$ were not considered. It is well known in literature that the greater the proportion of amylopectin, the lower the temperature required for the starch gelatinization (Liu, Zhang and Laskowski, 2000). A linear model was obtained with fit $\left(\mathrm{r}^{2}\right)$ around $98 \%$, which can be considered adequate.
Table 1 shows the average initial and final $\mathrm{pH}$ for the gelatinization tests and the average $\mathrm{NaOH}$ consumed at the turning point. It is possible to notice that cornstarch acidifies the solution after its dilution in the begging of the process. At the turning point, the average $\mathrm{pH}$ of the solution was above 12 for all tested temperatures, except for $65^{\circ} \mathrm{C}$. This happened because no $\mathrm{NaOH}$ was added to the solution and therefore the $\mathrm{pH}$ remained the same. It is also possible to notice that the experimental errors (represented by the standard deviation) in the $\mathrm{NaOH}$ consumed where lower than $10 \%$, being the higher experimental error obtained for temperature of $55^{\circ} \mathrm{C}$ with error of $0.62 \mathrm{~mL}$.
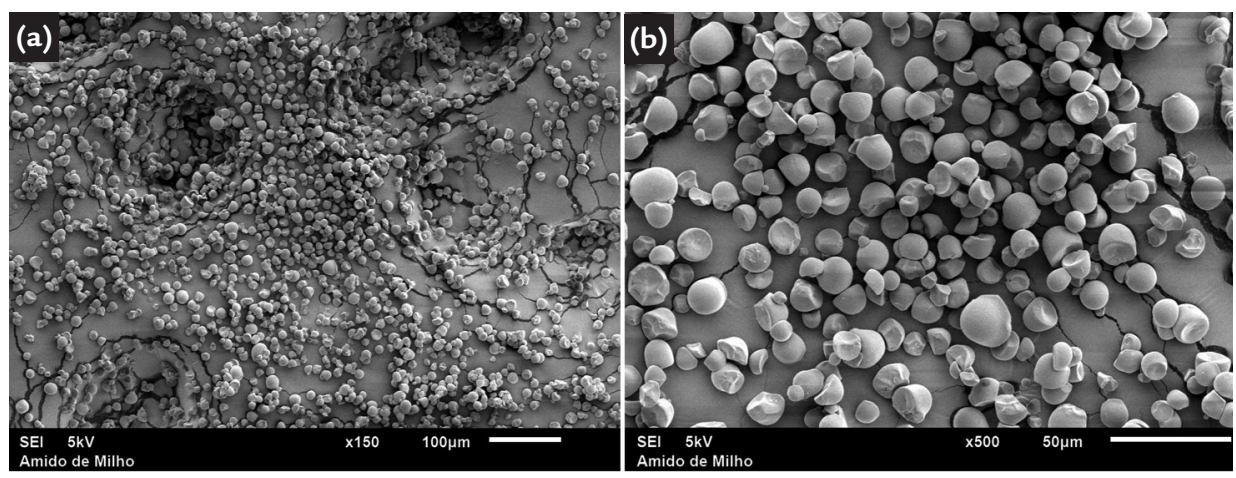

Figure 2 SEM images for cornstarch sample. Magnification (a) $\times 150$, (b) $\times 500$, (c) and (d) $\times 3,000$.
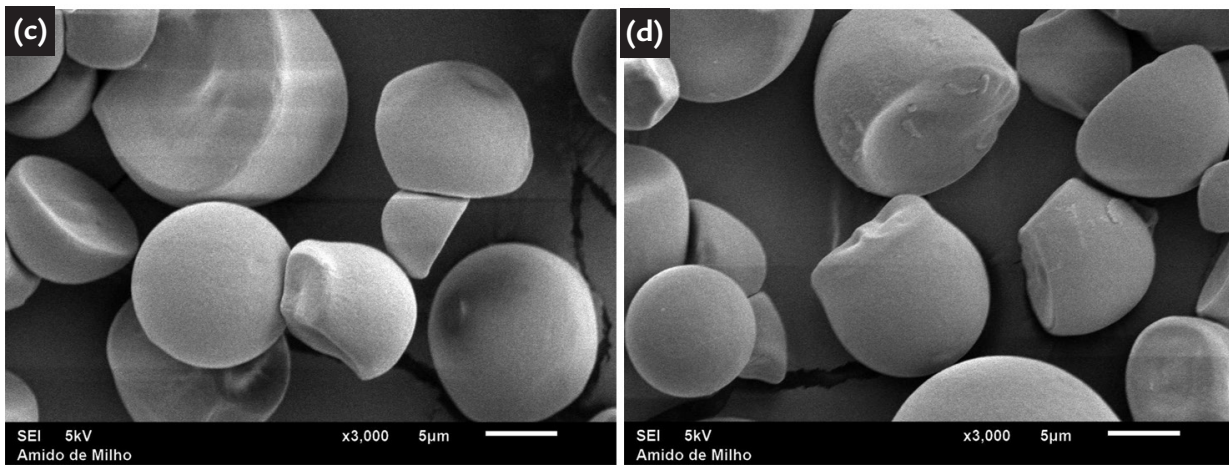


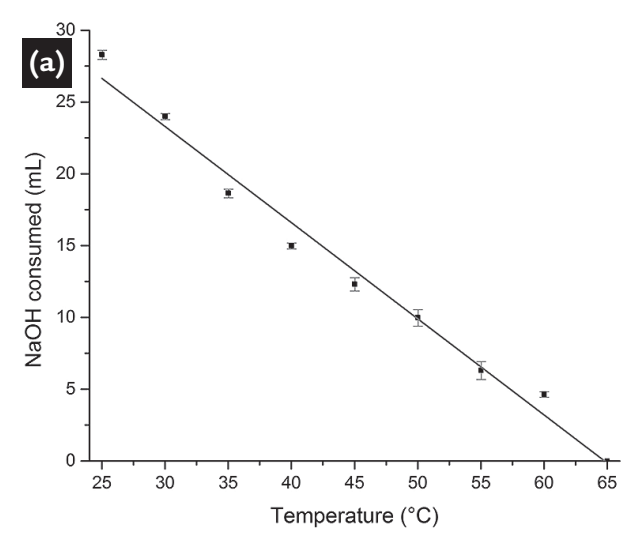

(b)

\begin{tabular}{|c|c|c|c|c|c|}
\hline \multirow{2}{*}{$\begin{array}{l}\text { Temperature } \\
\qquad\left({ }^{\circ} \mathrm{C}\right)\end{array}$} & \multirow{2}{*}{$\begin{array}{c}\text { Average initial } \\
\mathrm{pH}\end{array}$} & \multirow{2}{*}{$\begin{array}{c}\text { Average } \mathrm{pH} \\
\text { at turning } \\
\text { point }\end{array}$} & \multirow{2}{*}{$\begin{array}{l}\text { Average } \mathrm{NaOH} \\
\text { consumed at } \\
\text { the turning } \\
\text { point }(\mathrm{mL})\end{array}$} & \multicolumn{2}{|c|}{$\begin{array}{c}\text { Standard deviation of } \mathrm{NaOH} \\
\text { consumption }\end{array}$} \\
\hline & & & & $(\mathrm{mL})$ & (\%) \\
\hline 25 & 5.53 & 12.87 & 28.3 & 0.32 & 1.14 \\
\hline 30 & 5.36 & 12.73 & 24.0 & 0.21 & 0.88 \\
\hline 35 & 5.19 & 12.91 & 18.7 & 0.30 & 1.62 \\
\hline 40 & 5.17 & 12.83 & 15.0 & 0.20 & 1.33 \\
\hline 45 & 5.29 & 12.77 & 12.3 & 0.47 & 3.79 \\
\hline 50 & 5.32 & 12.46 & 10.0 & 0.58 & 5.77 \\
\hline 55 & 5.52 & 12.09 & 6.3 & 0.62 & 9.86 \\
\hline 60 & 5.31 & 12.01 & 4.7 & 0.19 & 4.02 \\
\hline 65 & 5.21 & 5.21 & 0.0 & - & - \\
\hline
\end{tabular}

Studies aiming the starch gelatinization process and its implication in flotation are still incipient in the literature. However, extensive work have been done in the food area. Santiago-Ramos et al (2017)

\section{Conclusions}

The cornstarch used in the experiments had characteristics similar to that described in literature. Although some broken and irregular grains where seen in SEM images no protein ribbons were noted. Regarding the amylose/ amylopectin ratio, the cornstarch was similar to results found for natural (or non-modified) starches.

The use of $\mathrm{NaOH}$ titration presented itself as an easy, but powerful, tool for studying the $\mathrm{NaOH}$ consumption needed in the gelatinization of the cornstarch,

\section{Acknowledgements}

The authors thank financial support from the Brazilian agencies CNPq, soft). According to the authors the starches gelatinization process started in $59.79^{\circ} \mathrm{C}$ studied the thermal properties of three different Mexican maize starches regarding the grain hardness (hard, intermediate and showing a linear relationship between temperature and $\mathrm{NaOH}$ consumption. Understanding this relationship is critical for mineral processing, specifically for froth flotation, since it may be possible to achieve a complete gelatinization of cornstarch with lower amounts of $\mathrm{NaOH}$ by changing the temperature. A temperature difference of $5^{\circ} \mathrm{C}$ (from 25 to $30^{\circ} \mathrm{C}$, acceptable for Brazilian weather) means that it is possible to reduce around $215 \mathrm{~L}$ of $\mathrm{NaOH}$ (or 496.65 $\mathrm{kg}$ of $\mathrm{NaOH}$ ) per ton of cornstarch in its
CAPES, FAPEG and FUNAPE. In addition, we like to thank Cargilll for the

\begin{tabular}{|c|c|c|}
\hline Equation & \multicolumn{2}{|c|}{$y=\mathrm{a}+\mathrm{b}^{*} \mathrm{x}$} \\
\hline Weight & \multicolumn{2}{|c|}{ No Weighting } \\
\hline Residual Sum of Squares & \multicolumn{2}{|c|}{10.49516} \\
\hline Pearson's $r$ & \multicolumn{2}{|c|}{-0.99229} \\
\hline Adj. R-Square & \multicolumn{2}{|c|}{0.98244} \\
\hline & Value & Standard Error \\
\hline Intercept & 43.38533 & 1.48009 \\
\hline Slope & -0.6696 & 0.03162 \\
\hline
\end{tabular}

Figure 3

(a) Influence of

the temperature in the $\mathrm{NaOH}$

consumption for cornstarch gelatinization and (b) linear regression parameters.

Table 1

Average initial and final $\mathrm{pH}$

for the gelatinization tests and

average $\mathrm{NaOH}$ consumed at turning point.

for soft, $61.67{ }^{\circ} \mathrm{C}$ for intermediate and $63.28^{\circ} \mathrm{C}$ for hard grains being the peak gelatinization temperature at $67.64,69.88$ and $72.33{ }^{\circ} \mathrm{C}$, respectively, which agree with the found results. gelatinization. This represents $15 \%$ of the $\mathrm{NaOH}$ consumption in the process, leading to a reduction of US $\$ 273.16$ per ton of cornstarch, considering the price of $\mathrm{NaOH}$ as US\$ 550.00 per ton. If the temperature variation is even higher, for example a temperature possible to be reached in Brazil's summer such as $35^{\circ} \mathrm{C}$ during the day and $25^{\circ} \mathrm{C}$ or lower at night, the reduction in $\mathrm{NaOH}$ could easily reach $480 \mathrm{~L}$ (or $1108.80 \mathrm{~kg}$ of $\mathrm{NaOH}$ ) per ton of cornstarch (reduction of approximately $34 \%$ ). samples donation, Federal University of Goiás and Goiano Federal Institute. 


\section{References}

BRANDÃO, P. R. G., CAIRES, L. G., QUEIROZ, D. S. B. Vegetable lipid oil based collectors in the flotation of apatite ores. Minerals Engineering, v.7, n.7, p.917-925, 1994.

COOKE, S. R. B., SCHULTZ, N. F., LINDROOS, E. W. The effect of certain starches on quartz and hematite suspensions. Trans. AIME, v.193, p.697-698, 1952.

DENARDIN, C. C., SILVA, L. P. Estrutura dos grânulos de amido e sua relação com propriedades físico-químicas. Revista Ciência Rural, v.39, n.3, p.945-954, 2009.

FILLIPOV, L. O., SEVEROV, V. V., FILLIPPOVA, I. V. Mechanism of starch adsorption on Fe-Mg-Al-bearing amphiboles. International Journal of Mineral Processing. v.123, p.120-128, 2013.

FILLIPOV, L. O., SEVEROV, V. V., FILLIPPOVA, I. V. An overview of the beneficiation of iron ores via reverse cationic flotation. International Journal of Mineral Processing. v.127, p.62-69, 2014.

GUIMARÃES, R. C., ARAÚJO, A. C., PERES, A. E. C. Reagents in igneous phosphate ores flotation. Minerals Engineering. v.18, n.2, p.199-204, 2005.

IBRAHIM, S. S., ABDEL-KHALEK, N. A. The action of different types of cornstarch on the flocculation of phosphate slimes. Minerals Engineering. v.5, n.8, p.907-916, 1992.

IWASAKI, I., CARLSON, W. J., PARMETER, S. M. The use of starches and starch derivatives as depressants and flocculants in iron ore beneficiation. Trans. ASME AIME. v. 224, p.88-98, 1969.

IWASAKI, I., LAI, R. W. Starches and starch products as depressants in soap flotation of activated silica from iron ores. Trans. Am. Inst. Min. Metall. Pet. Eng. v.232, n. 364, p.364-371, 1965.

KAR, B., SAHOO, H., RATH, S. S., DAS, B. Investigations on different starches as depressants for iron ore flotation. Minerals Engineering. v.49, p.1-6, 2013.

LEACH, H. W., MCCOWEN, L. D., SCHOCH, T. J. Structure of starch granule - I. Swelling and solubility patterns of various starches. Cereal Chemistry. v.36, n.6, p.534-544, 1959.

LEAL FILHO, L. S., ASSIS, S. M., ARAÚJO, A. C., CHAVES, A. P. Process mineralogy studies for optimizing the flotation performance of two refractory phosphate ores. Minerals Engineering. v.6, n.8-10, p.907-917, 1993.

LIU, Q., ZHANG, Y., LASKOWSKI, J. S. The adsorption of polysaccharides onto mineral surfaces: an acid/base interaction. International Journal of Mineral Processing. v.60, n.3-4, p.229-245, 2000.

MIKHAILOVA, N. S. Research of interaction of starch with oxides and silicates. Obogashenie Rud. v.6, p.20-23, 1972.

PERES, A. E. C., CORRÊA, M. I. Depression of iron oxides with cornstarches. Minerals Engineering. v.9, n.12, p.1227-123, 1996.

PINTO, C. L. L., ARAÚJO, A. C., PERES, A. E. C. The effect of starch, amylose and amylopectin on the depression of oxi-minerals. Minerals Engineering. v.5, n.3-5, p.469-478, 1992.

SANTIAGO-RAMOS, D., FIGUEROA-CÁRDENAS, J. D., VÉLES-MEDINA, J. J., MARISCAL-MORENO, R. M. Changes in the thermal and structural properties of maize starch during nixtamalization and tortilla-making processes as affected by grain hardness. Journal of Cereal Science. 2017. (In press).

SHRIMALI, K., MILLER, J. D. Polysaccharide depressants for the reverse flotation of iron ore. Transactions of the Indian Institute of Metals. v.69, n.1, p.83-95, 2016.

TURRER, H. D. G., PERES, A. E. C. Investigation on alternative depressants for iron ore flotation. Minerals Engineering. v.23, v.11-13, p.1066-1069, 2010.

WEISSENBORN, P. K. Behaviour of amylopectin and amylose components of starch in the selective flocculation of ultrafine iron ore. International Journal of Mineral Processing. v.47, n.3-4, p.197-211, 1996.

Received: 13 June 2016 - Accepted: 01 February 2017. 